UCRL --15943

DE88 000749

\title{
HIGH TEMPERATURE TESTING OF THE EDCON BOREHOLE GRAVITY HOUSING SYSTEM CONDUCTED AT LOS ALAMOS NATIONAL LABORATORIES
}

January $12-18,1986$

\section{DISCLAIMER}

This report was prepared as an account of work sponsored by an agency of the United States Government. Neither the United States Government nor any agency thereof, nor any of their employees, makes any warranty, express or implied, or assumes any legal liability or responsibility for the accuracy, completeness, or usefulness of any information, apparatus, product, or process disclosed, or represents that its use would not infringe privately owned rights. Reference herein to any specific commercial product, process, or service by trade name, trademark, manufacturer, or otherwise does not necessarily constitute or imply its endorsement, recommendation, or favoring by the United States Government or any agency thereof. The views and opinions of authors expressed herein do not necessarily state or reflect those of the United States Government or any agency thereof.

EDCON, INC.

Lakewood Place

12136 West Bayaud Street Lakewogd Col orado 80228 


\section{DISCLAIMER}

This report was prepared as an account of work sponsored by an agency of the United States Government. Neither the United States Government nor any agency Thereof, nor any of their employees, makes any warranty, express or implied, or assumes any legal liability or responsibility for the accuracy, completeness, or usefulness of any information, apparatus, product, or process disclosed, or represents that its use would not infringe privately owned rights. Reference herein to any specific commercial product, process, or service by trade name, trademark, manufacturer, or otherwise does not necessarily constitute or imply its endorsement, recommendation, or favoring by the United States Government or any agency thereof. The views and opinions of authors expressed herein do not necessarily state or reflect those of the United States Government or any agency thereof. 


\section{DISCLAIMER}

Portions of this document may be illegible in electronic image products. Images are produced from the best available original document. 


\section{TABLE OF CONTENTS}

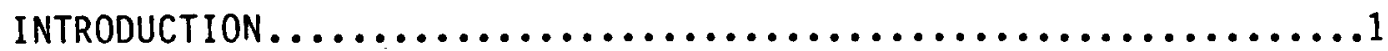

SYSTEM DESCRIPTION....................................2

TESTING FACILITIES............................4

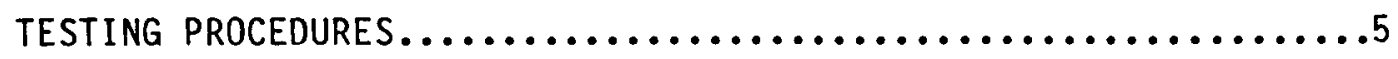

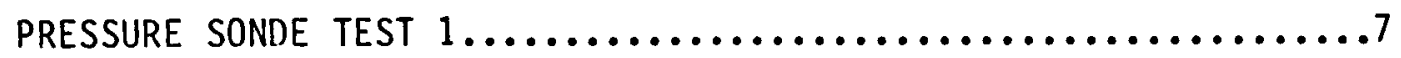

PRESSURE SONDE TEST $2 \ldots \ldots \ldots \ldots \ldots \ldots \ldots \ldots \ldots \ldots \ldots \ldots$

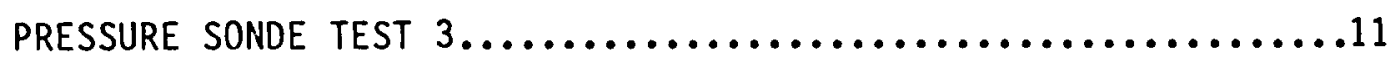

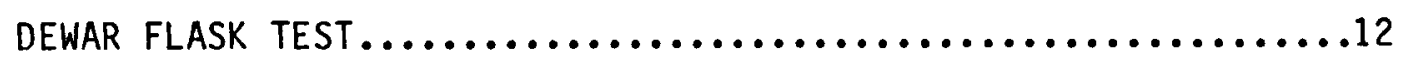

CONCLUSIONS AND RECOMMENDATIONS $\ldots \ldots \ldots \ldots \ldots \ldots \ldots \ldots \ldots \ldots \ldots$

APPENDIX......................................... 
INTRODUCTION

A series of tests were conducted from January 12 to 18,1986 upon the EDCON borehole gravity meter (BHGM) high temperature sonde at the LOS Alamos National Laboratory (LANL) Instrument Sonde Test Facility, Technical Area \#33, Los Alamos, New Mexico. The tests were conducted to determine the suitability of this sonde for logging operations in the Department of Energy Salton Trough test well. 


\section{SONDE ASSEMBLY}

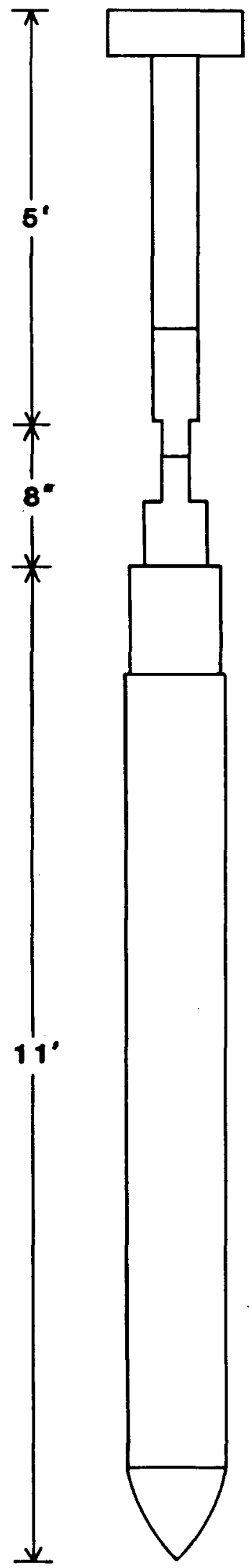

$\longleftarrow$ LANL ISTF HEAD ASSEMBLY

$\longleftarrow$ LANL TO GO SUB $\left(O D=2.5^{\circ}\right)$

$\longleftarrow . O D=1.6^{\circ}$

$\longleftarrow$ GO TO SCHLUMBERGER SUB (EDCON) $\left(O D=3.4^{\circ}\right)$

$\longleftarrow$ EDCON CROSSOVER SUB $\left(O D=5.0^{\circ}\right)$

$\longleftarrow$ EDCON HIGH TEMPERATURE SONDE $\left(O D=5.25^{\circ}\right)$

NOTE: NOT TO SCALE $O D=$ OUTSIDE DIAMETER 


\section{SYSTEM DESCRIPTION}

The BHGM sonde is a 5.25 inch outside diameter plated steel pressure tube approximately 11 feet long, designed to withstand pressures of 20,000 psi. A Dewar flask fits inside this pressure tube to isolate the BHGM instrumentation from the outside well temperatures. The design specifications for this unit were to provide at least 30 hours of operation at temperatures up to $400^{\circ} \mathrm{F}$.

The bottom of the pressure tube is terminated by a "bullnose" plug which screws into the tube. 0-rings provide leak protection about this join.

At the top of the pressure tube is a crossover sub designed to allow a standard Schlumberger compatible ten-pin cable head to be mated to the top of the tool. Several 0-rings provide leak protection between the sub to pressure tube join, within the sub itself and between the cable head and the sub.

It is most likely that the logging at the Salton Trough well will take place from a U.S.G.S. owned high temperature wireline cable. The normal cable head used on this wireline is a Gearhart-Owens $(G / 0)$ type head. The system tested (Figure 1) was therefore designed to be compatible with a G/0 type of head. A Schlumberger to $G / 0$ crossover sub was therefore connected to the top of the normal EDCON Schlumberger crossover sub. The top of the $6 / 0$ Schlumberger crossover sub was then connected to a cable head manufactured by LANL via another sub, also manufactured by LANL. The field system would not require the LANL cable head and sub. 
The G/0 to Schlumberger crossover sub was not originally designed for high temperature operations. Prior to the test; this sub was upgraded by replacing low temperature wiring, solder, insulation, grease, and 0 -rings with materials rated to $300^{\circ} \mathrm{C}$. The electrical isolation between conductors in this crossover was checked in a dry oven test to $260^{\circ} \mathrm{C}$ at EDCON in Denver prior to the LANL tests. Insulation resistance deteriorated to 20 megohms during the Denver tests. A point of concern was that dissimilar metals were used in the construction of this sub and differential expansion would occur at the high temperatures in the Salton Trough well, allowing some leaks to occur. This sub has been previously used in petroleum wells at temperatures up to $115^{\circ} \mathrm{C}$ and pressures up to 8000 PSI.

The many different connecting subs used to connect the LANL head to the BHGM sonde provide several possible failure points. An obvious way to minimize the number of potential failure points would be to manufacture a new cable head to attach directly to the BHGM sonde. 


\section{TESTING FACILITIES}

The testing facilities were provided by LANL at Technical Area 33 (TA-33) in the main laboratory complex. Two test chambers were used.

The instrument Sonde Test Facility (ISTF) is a vertical autoclave capable of testing tools up to 8.5 in (28 feet) 1 ong and $152 \mathrm{~mm}$ ( 6 inch) diameter. A temperature of $275^{\circ} \mathrm{C}\left(527^{\circ} \mathrm{F}\right)$ is achievable at fluid pressures of 6000 psi (41.4 MP $\mathrm{a}$ ). Higher temperatures may be achieved at lower fluid pressures. An overhead workover tower provides cranes to assist the placing of the test tools in the autoclave. Seven conductors allow the internal sonde resistances to be monitored.

A National $K$ Works environmental muffled oven, Model 65-156 is used for dry thermal testing of thermal protection systems. It operates to temperatures of $500^{\circ} \mathrm{C}\left(932^{\circ} \mathrm{F}\right)$ using a programmed controller. It accepts tools up to $3.6 \mathrm{~m}(12 \mathrm{ft})$ long and $152 \mathrm{~mm}$ ( 6 inch) diameter.

These test facilities are described by Dennis, et al, 1985. 


\section{TESTING PROCEDURE}

The tests had a threefold purpose:

1. To check the pressure seal system under temperatures up to $300^{\circ} \mathrm{C}$ $\left(572^{\circ} \mathrm{F}\right)$ and pressures up to $34.5 \mathrm{MP}_{\mathrm{a}}(5000 \mathrm{psi})$

2. To check the electrical integrity of the system under these conditions

3. To check the Dewar flask behavior at these temperatures and determine an operating time for the complete BHGM system at these temperatures

The first two of the above items were tested in the vertical autoclave (ISTF). The third was tested in the dry thermal oven. 
TABLE 1

Date 1-13-86

$\begin{array}{lccc}\text { Time } & \text { Pressure } & \text { Fluid Temperature } & \text { Heater Temperature } \\ (\text { MST }) & (\text { PSI }) & \left({ }^{\circ} \mathrm{C}\right) & \left({ }^{\circ} \mathrm{C}\right)\end{array}$

\begin{tabular}{|c|c|c|c|}
\hline 1810 & 802 & 36 & $\star 58$ \\
\hline 1825 & 2300 & 54 & 274 \\
\hline 1840 & 2750 & 73 & 292 \\
\hline 1850 & 2712 & 85 & 296 \\
\hline 1905 & 3975 & 106 & 290 \\
\hline 1915 & 3741 & 118 & 278 \\
\hline 1930 & 3728 & 132 & 286 \\
\hline 1945 & 3653 & 150 & 288 \\
\hline 2000 & 3684 & 162 & 300 \\
\hline 2015 & 3643 & 177 & $\star \star 312$ \\
\hline 2020 & 3298 & 185 & - \\
\hline 2037 & 3348 & 195 & - \\
\hline 2045 & 3426 & 202 & - \\
\hline 2050 & 3569 & 208 & - \\
\hline 2120 & 3584 & 234 & 340 \\
\hline 2130 & 3526 & 241 & 333 \\
\hline 2145 & 3580 & 251 & 331 \\
\hline 2150 & 3733 & 252 & 327 \\
\hline 2155 & 4230 & 254 & 314 \\
\hline 2200 & 4300 & 255 & 284 \\
\hline 2213 & 4360 & 254 & 338 \\
\hline 2235 & 4363 & 258 & 321 \\
\hline 2330 & 4350 & 259 & 306 \\
\hline 2400 & 4350 & 260 & 291 \\
\hline & & Date $1-14-86$ & \\
\hline 1145 & 0 & 107 & 115 \\
\hline 1200 & 0 & 100 & 81 \\
\hline 1205 & 0 & 100 & $\star \star \star 95$ \\
\hline 1210 & 300 & 78 & 93 \\
\hline 1213 & 600 & 76 & 93 \\
\hline 1220 & 3200 & 80 & 96 \\
\hline 1228 & 4350 & 82 & 98 \\
\hline 1250 & 3500 & 85 & 102 \\
\hline 1255 & - & 85 & 102 \\
\hline 1258 & 800 & 85 & 102 \\
\hline 1313 & 0 & 67 & 88 \\
\hline 1318 & 0 & 64 & 85 \\
\hline 1342 & 0 & 56 & 75 \\
\hline
\end{tabular}

*electrical isolation good

**electrical isolation bad

$\star \star \star$ conductor isolation good 


\section{PRESSURE SONDE TEST 1}

The sonde assembly shown in Figure 1 was lowered into the autoclave after raising it from a horizontal position. Bending of this assembly at the $G / 0$ crossover sub was noted and human strength was used to lessen this bending during the pick up. Table 1 shows the temperature and pressure record for this test. These records are shown graphically in Figures 2,3 , and 4 . Figure 5 is a conversion graph to derive true autoclave pressures from the meter pressures shown in Figure 1.

A pressure drop of about 400 psi occurred at 8.25 hours. After ten hours, the pressure and temperature were steady at about 5000 psi and $260^{\circ} \mathrm{C}$ respectively. This state continued until the test was stopped at 12 hours.

The resistance between each of the seven conductors and ground was periodically checked during the test with a "meggermeter". These results are shown in Table 2.

\section{TABLE 2}

Time

Up to 8.25

9.00

9.75

12.00

\section{Resistance}

$10 X$
$1-2 M X$
$.5 M X$
$.15 M X$

The nature of the pressure drop and recovery suggested that water had passed an 0-ring into a small cavity and had been prevented from going farther by another 0-ring seal. Upon disassembling the system, the most likely place found for this to have happened was in the LANL to G/O crossover sub where the 
0-rings had degraded and an amphenol electrical connector was cracked. Multiple small leaks noticed in the autoclave plumbing during the test were identified and repaired. The other seals and backup rings in the system looked good on inspection.

This test indicates that apart from the LANL to G/O connector sub failure, the system maintained its pressure seal at 5000 psi and $260^{\circ} \mathrm{C}$. The electrical insulation was probably invaded by fluid in the LANL to G/O sub and no conclusions can be drawn about the electrical integrity of the other parts of the system.

TABLE 3

Date 1-15-86

$\begin{array}{lccc}\text { Time } & \text { Pressure } & \text { Fluid Temperature } & \text { Heater Temperature } \\ (\text { MST }) & (\text { PSI }) & \left({ }^{\circ} \mathrm{C}\right) & \left({ }^{\circ} \mathrm{C}\right)\end{array}$

\begin{tabular}{rrrr}
\hline 1730 & 26 & 47 & 59 \\
1748 & 486 & 60 & 255 \\
1800 & 2316 & 76 & 295 \\
1815 & 4382 & 97 & 323 \\
1820 & 4392 & 107 & $\star 321$ \\
1830 & 3744 & 116 & $\star \star 241$ \\
1845 & 2108 & 125 & 191 \\
1900 & 1120 & 127 & 170 \\
1915 & 457 & 129 & 150 \\
1930 & 181 & 129 & 145 \\
1944 & 977 & 127 & 135 \\
2000 & 416 & 127 & 133 \\
2015 & 126 & 127 & 135 \\
2030 & -127 & 130 \\
2045 & 647 & 125 & 128 \\
2115 & 301 & 127 & 125 \\
2215 & 500 & 122 & 119
\end{tabular}

*electrical leak

* *heaters off 


\section{PRESSURE SONDE TEST 2}

The damaged 0-rings and connectors identified during the first test were replaced, the system was assembled vertically to prevent stain on the G/O connector and then placed again in the autoclave.

Table 3 shows the time, temperature, and pressure records for this test. Upon reaching 50000 psi pressure and $107^{\circ} \mathrm{C}$, the lines again became electrically shorted to ground. The system was then cooled, disassembled, and inspected. No water leaks or connection problems were found. Upon cooling, the electrical leaks disappear.

It was suspected that the G/0 to Schlumberger crossover connection, being the only part of the system not al ready field proven in higher pressure and temperature conditions then experienced during this second test, was the likely source of electrical failure. 
TABLE 4

Date 1-16-86 - Pressure Test 3

\begin{tabular}{lccr}
$\begin{array}{c}\text { Time } \\
(\text { MST) }\end{array}$ & $\begin{array}{c}\text { Pressure } \\
\text { (PSI) }\end{array}$ & $\begin{array}{c}\text { Fluid Temperature } \\
\left({ }^{\circ} \mathrm{C}\right)\end{array}$ & $\begin{array}{c}\text { Heater Temperature } \\
\left({ }^{\circ} \mathrm{C}\right)\end{array}$ \\
\hline 1035 & 0 & 68 & $\star 68$ \\
1045 & 2500 & 68 & 68 \\
1050 & 3500 & 68 & 68 \\
1052 & 4000 & - & - \\
1055 & 4292 & - & $\star \star 85$ \\
1345 & 0 & 67 & 85 \\
1350 & 21 & 74 & 224 \\
1405 & 478 & 82 & 257 \\
1415 & 1443 & 97 & 288 \\
1430 & 3522 & 117 & 304 \\
1445 & 4382 & 120 & 232 \\
1448 & 4387 & 130 & 188 \\
1500 & 4091 & 137 & 173 \\
1518 & 3017 & 140 & 162 \\
1530 & 2691 & 140 & 142 \\
1545 & 2326 & 139 & 147 \\
1603 & 1931 & 139 & 141 \\
1616 & 1667 & 137 & \\
1634 & 1323 & 137 & \\
1645 & 1131 & &
\end{tabular}

*electrical isolation ok

$\star \star$ P ressure bled to start heater

$\star \star \star$ electrical shorts turn off heater 


\section{PRESSURE TEST 3}

A connector was replaced in the G/O to Schlumberger crossover sub and the system assembled once more in the autoclave. Electrical resistance was good when the pressure was raised to 5010 psi at a temperature of $68^{\circ} \mathrm{C}$. The pressure was then bled off and then increased with temperature until a pressure of about $5000 \mathrm{psi}$ and a temperature of $120^{\circ} \mathrm{C}$ was reached. At this point all lines except one showed electrical shorts. The pressure and temperature were lowered and the system disassembled.

Pressure Tests 2 and 3 both showed electrical isolation resistance between conductors dropped rapidly with increasing temperature. This did not occur with increased pressure at low temperature. The relatively sudden drop in the resistance between conductors once the temperature is raised above $100^{\circ} \mathrm{C}$ suggests that some moisture may be turning to steam and providing electrical leakage paths.

The 7 (seven) pin connectors from the LANL to G/O crossover and the EDCON to G/0 crossover were then placed in an air oven. The isolation resistances of the wires in these connectors began to degrade at $170^{\circ} \mathrm{C}$ and at $260^{\circ} \mathrm{C}$ were about 3 megohms. This does not explain the autoclave results as the air oven would have allowed the water vapor to dissipate from the connectors. Within the sonde, the pressure would rise within the isolated cavities containing the connectors, forcing water vapor into the connectors. 


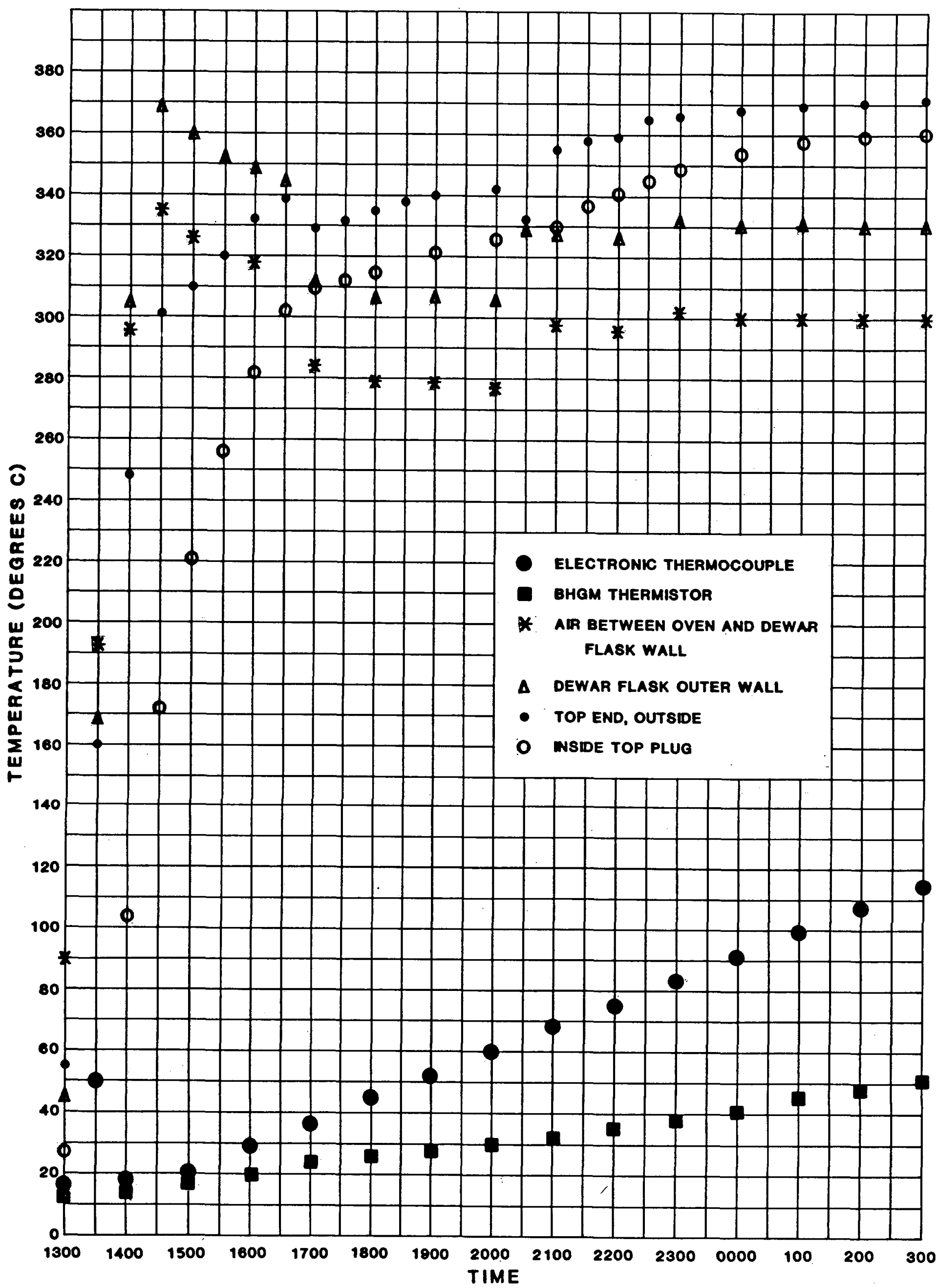




\section{DEMAR FLASK TEST}

The Dewar flask is used to isolate the BHGM and the downhole electronics from the high temperature well environment. This allows the electronic components to operate without failing due to heat and keeps the air surrounding the BHGM element below its thermostatting temperature of approximately $125^{\circ} \mathrm{C}$.

Since the thermostatting oven and the electronics both dissipate heat which is trapped within the Dewar, internal fusible metal heat sinks are used to prevent the temperature within the Dewar from rising too rapidly. The design specifications for the Dewar system specified that operation should be possible in a $400^{\circ}$ well environment for 30 hours. The highest temperature well logged to date was at $350^{\circ} \mathrm{F}$. The internal Dewar temperature after 24 hours of operation was $104^{\circ} \mathrm{C}$.

As the external temperature increases, the allowable time of operation will decrease. This test was run to estimate the allowable operation time at $300^{\circ} \mathrm{C}$. The BHGM was not placed in the Dewar for insurance reasons, but the heat sinks were installed.

Figure 2 shows the temperature as a function of time for several positions inside and outside the Dewar. Figure 3 shows the position of these heat sensors. 


\section{PLACEMENT DIAGRAM OF HEAT SENSORS IN LANL AIR OVEN TEST}

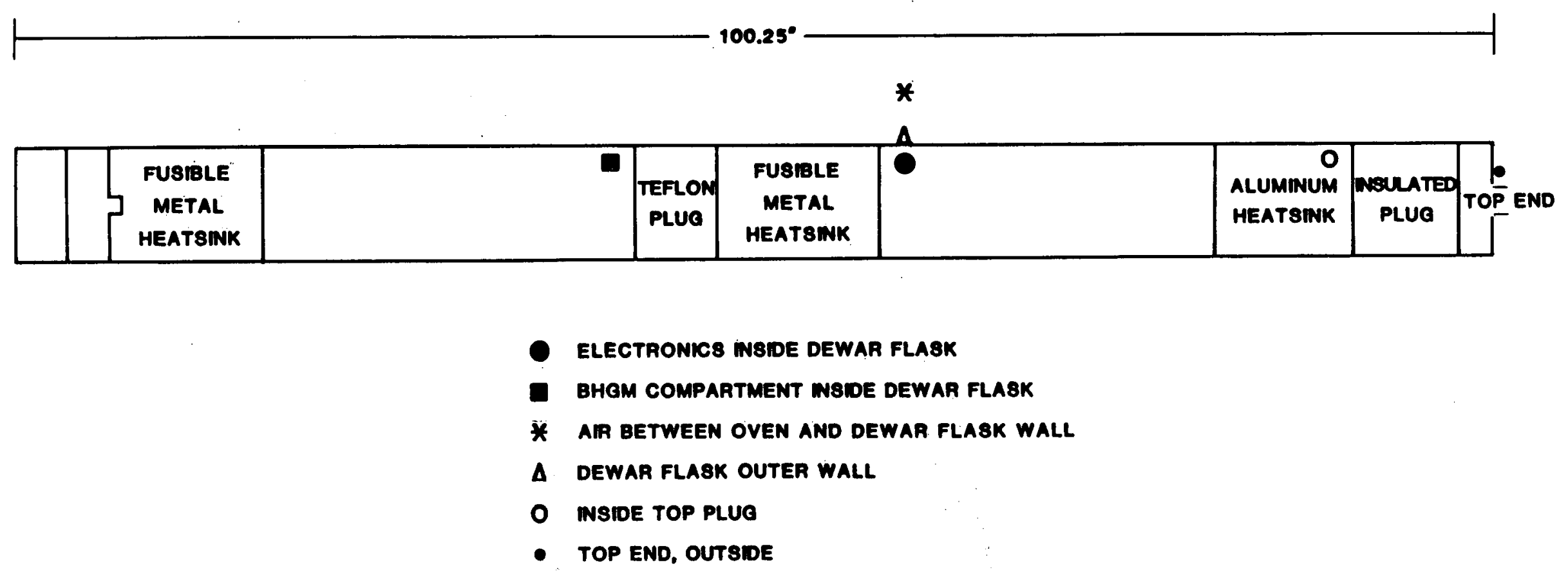


The thermocouple in the air outside the Dewar is the equivalent in this experiment of the well temperature. The BHGM thermistor and the electronic thermocouple are the temperatures which would be experienced by the electronics module and the BHGM element.

From these temperatures, it is possible to estimate the actual internal temperature after a certain immersion time with the BHGM inside the Dewar if we know the temperature history with the BHGM operating in the Dewar commencing at room temperature. From Appendix 1, the temperature after 10 hours operation at $300^{\circ} \mathrm{C}$ well temperatures should be about $96^{\circ} \mathrm{C}$, measured in the electronics compartment of the Dewar. The temperature in the BHGM element compartment should, according to all other tests done with this equipment, be slightly lower.

\section{CONCLUSIONS AND RECOMENDATIONS}

The results of these tests indicate that over short periods of time, the system tested provided a good pressure seal, apart from one failure in the crossover connector subs. Electrical leakage between the conductors is a problem above $100^{\circ}$. Dry heat tests on the downhole connectors show increasing leakage to about 3 megohms at $260^{\circ} \mathrm{C}$. Apparently moisture is present either through minor seal leakage or from the assembly of the components that is causing these electrical leaks. The probability of these leaks occurring could be decreased by simplifying the system of crossover connecting subs and paying careful attention to drying the connectors thoroughly before assembly.

The Dewar test indicated that the downhole operation should be able to run conservatively for 10 hours before the temperature begins to cause 
electronic component failures. The operating time may be extended by cooling the heat sinks to about $0^{\circ} \mathrm{C}$ before assembly. This runs the risk of introducing moisture to the system through condensation if the air humidity is high.

\section{REFERENCES}

"High Temperature Borehole Instrumentation", Dennis, B.R., Koezan, S.P., Stephani, E.L. Publication LA-10558-HDR, UC-666. Issued by Los Alamos National Laboratory, New Mexico, October 1985. 


\section{APPENDIX}

Consider two cases:

Case (1): The Dewar flask, including heat sinks, is placed in an oven from which an amount of heat $Q_{1}$ enters the Dewar in time $\tau$, raising the internal temperature of the Dewar and contents by $\Delta T$. Suppose the mass of the inside of the Dewar and the heatsinks is $M_{1}$ and they have an average specific heat of $\mathrm{S}_{1}$

$$
\text { Then } \Delta T_{1}=\frac{Q_{1}}{M_{1} S_{1}}=\frac{Q_{1}}{W_{1}}
$$

Case (2): The Dewar flask with the heat sinks and the BHGM installed is at room temperature. The BHGM is turned on for a time $\tau$ during which it emits a quantity of heat $Q_{2}$ and raises the temperature of the Dewar and contents by $\Delta T^{2}$.

The mass of the inside of the Dewar and contents is now $M_{1}+M_{2}$ and the average specific heat of the BHGM is $S_{2}$.

$$
\text { Then } \Delta T_{2}=\frac{Q_{2}}{M_{1} S_{1}+M_{2}+S_{2}}
$$

If the two cases are combined, i.e., the operating BHGM in the Dewar is immersed in an oven or well for time $\tau$ at the same external temperature as in case (1), the total heat introduced to the Dewar contents is 0 where

$$
Q=Q_{1}+Q_{2}
$$


We would like to calculate the change in temperature of the Dewar contents, $\Delta T$, over time $\tau$.

$$
\begin{aligned}
\Delta T & =\frac{Q}{W_{1}+W_{2}} \\
\text { i.e. } \Delta T & =\frac{Q_{1}+Q_{2}}{W_{1}+W_{2}} \\
& =\frac{W_{1}\left(\Delta T_{1}+\Delta T_{2}\right)+W_{2} \Delta T_{2}}{\left(W_{1}+W_{2}\right)}
\end{aligned}
$$

Actual values after 10 hours for $\Delta \mathrm{T}_{1}$ and $\Delta \mathrm{T}_{2}$ are $39^{\circ} \mathrm{C}$ and $65^{\circ} \mathrm{C}$ respectively. To estimate the specific mass for Case (1) and Case (2):

Mass of Dewar inside wall $7000 \mathrm{~g}$.

Specific heat $\sim .1 \mathrm{cal} / \mathrm{g} /{ }^{\circ} \mathrm{C}$

Mass of heat sinks $\sim 40000 \mathrm{~g}$

Specific neat $\sim .03 \mathrm{cal} / \mathrm{g} /{ }^{\circ} \mathrm{C}$

Therefore $W_{1} \sim 7000 \times .1+40000 \times .03=1900 \mathrm{cal} /{ }^{\circ} \mathrm{C}$. 


$$
\begin{aligned}
\text { Mass of BHGM } & \sim 20,0000 \mathrm{~g} \\
\text { Specific heat } & \sim .2 \mathrm{cal} / \mathrm{g} /{ }^{\circ} \mathrm{C} .
\end{aligned}
$$

$$
\text { Therefore } W_{2} \sim 20,000 \times .2 \sim 4000 \mathrm{cal} /{ }^{\circ} \mathrm{C} \text {. }
$$

Inserting values into equation (3) we have:

$$
\Delta T=\frac{1900(39+65)+4000 \times 65}{1900+4000}=77.6^{U}
$$

i.e. after 10 hours in a well at $300^{\circ} \mathrm{C}$ the internal temperature of the Dewar flask should be about $77.6^{\circ} \mathrm{C}$. 